\title{
An Unbalanced Chromosome Translocation Between 7p22 and 12q13 Leads to ACTB-GLI1 Fusion in Pericytoma
}

\author{
IOANNIS PANAGOPOULOS ${ }^{1}$, LUDMILA GORUNOVA ${ }^{1}$, TOR VIKAN RISE ${ }^{2}$, \\ KRISTIN ANDERSEN ${ }^{1}$, FRANCESCA MICCI ${ }^{1}$ and SVERRE HEIM ${ }^{1,3}$ \\ ${ }^{1}$ Section for Cancer Cytogenetics, Institute for Cancer Genetics and Informatics, \\ The Norwegian Radium Hospital, Oslo University Hospital, Oslo, Norway; \\ ${ }^{2}$ Department of Pathology, St. Olavs Hospital, Trondheim University Hospital, Trondheim, Norway; \\ ${ }^{3}$ Institute of Clinical Medicine, Faculty of Medicine, University of Oslo, Oslo, Norway
}

\begin{abstract}
Background/Aim: Since the first description of five pericytomas with the $t(7 ; 12) / A C T B-G L I 1$ fusion gene, only three new tumors were studied by both cytogenetics and molecular techniques. We report here genetic data on another case of this rare tumor. Materials and Methods: Cytogenetic, fluorescence in situ hybridization (FISH), reverse transcription polymerase chain reaction (RT-PCR), and Sanger sequencing analyses were performed. Results: The pericytoma carried two structurally rearranged chromosomes: $\operatorname{der}(7) t(7 ; 12)(p 22 ; q 13)$ and $\operatorname{der}(12) t(1 ; 12)(q 12 ; q 13)$. In FISH experiments with a breakapart probe for GLII, the distal part of the probe hybridized to $\operatorname{der}(7)$ whereas the proximal part to $\operatorname{der}(12)$. RT-PCR and Sanger sequencing detected an ACTB-GLII fragment in which exon 2 of ACTB was fused to exon 6 of GLII. Conclusion: The ACTB-GLIl fusion gene was mapped at $\operatorname{der}(7) t(7 ; 12)(p 22 ; q 13)$ and coded for a putative ACTB-GLII protein in which the first 41 amino acid (aa) of ACTB replaced the first 177 a a of GLII.
\end{abstract}

Fusion of the genes actin beta (ACTB on $7 \mathrm{p} 22.1)$ and glioma associated oncogene homologue 1 (GLII on 12q13.3) was first reported by Dahlén et al. $(1,2)$ in five benign spindle cell tumors with distinctive pericytic features and a $\mathrm{t}(7 ; 12)(\mathrm{p} 21-22 ; \mathrm{q} 13-15)$ chromosome translocation. The tumors defined a discrete group of previously uncharacterized neoplasms for which the term

This article is freely accessible online.

Correspondence to: Ioannis Panagopoulos, Section for Cancer Cytogenetics, Institute for Cancer Genetics and Informatics, The Norwegian Radium Hospital, Oslo University Hospital, Montebello, PO Box 4954 Nydalen, NO-0424 Oslo, Norway. Tel: +47 22782362, e-mail: ioannis.panagopoulos@rr-research.no

Key Words: Pericytoma, $\mathrm{t}(7 ; 12), A C T B-G L I 1$ fusion gene, GLI1 isoform 2 protein, unbalanced chromosome translocation. "pericytoma with $\mathrm{t}(7 ; 12)$ " was proposed in order to reflect both the morphological and cytogenetic features (1). Until now, the ACTB-GLII fusion gene has been reported in fifteen such cases, four of which had developed metastases (1-7) (Table I). Because of the apparent rarity of tumors carrying a $\mathrm{t}(7 ; 12) / A C T B-G L I 1$, we here present the genetic and clinical features of another pericytoma with an unbalanced chromosome translocation between 7 p22 and 12q13 leading to an $A C T B-G L I I$ fusion gene.

\section{Materials and Methods}

Case description and pathology. An 83-year-old woman presented with a painless palpable mass in her left thigh. Magnetic resonance imaging (MRI) revealed a $4 \times 11 \times 10 \mathrm{~cm}$ encapsulated, mainly cystic tumor in the adductor magnus muscle. There was contrast enhancement in the capsule and a small intracapsular part of the tumor. Staging studies revealed no evidence of metastatic disease. Examination of the core needle biopsy showed a small blue round cell tumor with low mitotic activity. Immunohistochemistry showed that the tumor cells were positive for CD99 (Figure 1A), and fluorescence in situ hybridization (FISH) showed no rearrangement of EWSR1.

Wide tumor excision was performed. Gross examination revealed a cystic tumor with a maximum diameter of $9.5 \mathrm{~cm}$. The cystic tumor was filled with serous fluid and grey, necrotic appearing material. In the internal part of the fibrous capsule, there was a white and solid layer 3-15 mm thick (Figure 1B). The tumor demonstrated sheetlike growth with an intricate network of capillary-sized vessels (Figure 1C). In the fibrous capsule there was evidence of tumor cells around larger vessels (Figure 1D). The neoplastic cells were small and ovoid with sparse eosinophilic cytoplasm and round nuclei with dense chromatin and scattered small white pseudoinclusions. The ratio of mitoses was $1 / 10$ highpower field (HPF), no atypical mitotic figures were noted. Immunohistochemical staining showed that the tumor cells were positive for cluster of differentiation (CD) CD99 (strong membranous, weak cytoplasmic positivity), alpha-smooth muscle actin (SMA weak), cytokeratin AE1/AE3 (CK ae1/ae3 weak and focal), epithelial membrane antigen (EMA weak and focal), and berep4 (weak and focal). Staining for CD34 and CD31 highlighted 
Table I. The currently reported pericytomas with the ACTB-GLII fusion gene including the present tumor.

\begin{tabular}{|c|c|c|c|c|c|}
\hline Case & Gender/Age & Location & Karyotype & $\begin{array}{l}\text { Fused exons in } \\
\text { ACTB-GLII transcript }\end{array}$ & Reference \\
\hline 1 & $\mathrm{M} / 61$ & Calf & $\begin{array}{l}45, \mathrm{XY}, \mathrm{t}(7 ; 12)(\mathrm{p} 22 ; \mathrm{q} 13), \operatorname{inv}(10)(\mathrm{p} 11 \mathrm{q} 21) \mathrm{c} \\
\operatorname{der}(15 ; 16)(\mathrm{q} 10 ; \mathrm{p} 10)\end{array}$ & Exon $2-$ Exon 7 & (1) \\
\hline 2 & $\mathrm{~F} / 27$ & Tongue & $46, \mathrm{XX}, \mathrm{t}(7 ; 12)(\mathrm{p} 22 ; \mathrm{q} 13)$ & Exon $1-$ Exon 6 & (1) \\
\hline 3 & $\mathrm{M} / 11$ & Tongue & $\begin{array}{l}45, \mathrm{XY}, \operatorname{der}(1) \mathrm{t}(1 ; ? 7)(\mathrm{p} 36 ; \mathrm{p} ? 22), \operatorname{add}(2)(\mathrm{p} 25), \operatorname{add}(5)(\mathrm{p} 15), \operatorname{add}(6) \\
(\mathrm{p} ? 21), \operatorname{der}(7) \mathrm{t}(7 ; 12)(\mathrm{p} 11 ; \mathrm{p} 11), \operatorname{der}(7) \mathrm{t}(7 ; 12)(\mathrm{p} 21 ; \mathrm{q} 1 ? 5),-12\end{array}$ & Exon 3 - Exon 7 & (1) \\
\hline 4 & $\mathrm{~F} / 65$ & Stomach & $46, \mathrm{XX}, \mathrm{t}(7 ; 12)(? \mathrm{p} 22 ; ? \mathrm{q} 15)$ & Exon 2 - Exon 6 & (1) \\
\hline 5 & $\mathrm{~F} / 12$ & Tongue & $46, \mathrm{XX}, \mathrm{t}(1 ; 3)(\mathrm{p} 22 ; \mathrm{q} 21), \mathrm{t}(7 ; 12)(\mathrm{p} 22 ; \mathrm{q} 13)$ & Exon 3 - Exon 6 & (1) \\
\hline 6 & $\mathrm{M} / 67$ & Skeleton & $\begin{array}{l}46, \mathrm{XY},+\mathrm{X}, \operatorname{der}(1) \mathrm{t}(1 ; 14)(\mathrm{p} 13 ; \mathrm{q} 11), \operatorname{der}(2) \mathrm{t}(2 ; 13) \\
(\mathrm{q} 31 ; \mathrm{q} 31), \operatorname{der}(3) \mathrm{t}(2 ; 13 ; 3)(\mathrm{q} 31 ; \mathrm{q} 11-31 ; \mathrm{p} 13) \\
\mathrm{t}(7 ; 12)(\mathrm{p} 22 ; \mathrm{q} 13),-13, \operatorname{der}(? 14) \mathrm{t}(13 ; ? 14 ; ?) \\
(\mathrm{q} 11-12 ; ? \mathrm{q} 11 ; ?), \operatorname{der}(15) \mathrm{t}(3 ; 15)(\mathrm{p} 13 ; \mathrm{q} 11)\end{array}$ & Exon 3 - Exon 6 & (3) \\
\hline 7 & $\mathrm{~F} / 9$ & Stomach & $46, \mathrm{XX}, \mathrm{t}(7 ; 12)(\mathrm{p} 22 ; \mathrm{q} 13)$ & Exon 2 - Exon 6 & (4) \\
\hline 8 & $\mathrm{~F} / 11$ & Ovary & $46, \mathrm{XX}, \mathrm{t}(7 ; 12)(\mathrm{p} 22 ; \mathrm{q} 13)$ & Exon 3 - Exon 6 & (7) \\
\hline 9 & $\mathrm{M} / 20$ & Thigh & No data & Exon 3 - Exon 6 & (5) \\
\hline 10 & $\mathrm{~F} / 30$ & Foot & No data & No data & (5) \\
\hline 11 & $\mathrm{~F} / 79$ & Retroperitoneum & No data & Exon 1-Exon 5 & (5) \\
\hline 12 & $\mathrm{~F} / 38$ & $\begin{array}{l}\text { Chest wall } \\
\text { (skeletal muscle) }\end{array}$ & No data & No data & (5) \\
\hline 13 & $\mathrm{~F} / 57$ & Tibia & No data & No data & (6) \\
\hline 14 & $\mathrm{M} / 62$ & Scapula & No data & No data & (6) \\
\hline 15 & $\mathrm{~F} / 41$ & Ovary & No data & No data & (6) \\
\hline 16 & $\mathrm{~F} / 83$ & Thigh & $\begin{array}{l}\text { 46,XX,der(7)t }(7 ; 12)(\mathrm{p} 22 ; \mathrm{q} 13), \operatorname{der}(12) \mathrm{t}(1 ; 12) \\
(\mathrm{q} 12 ; \mathrm{q} 13)[11] / 46, \text { idem,tas }(\mathrm{X} ; 8)(\mathrm{qter} ; \mathrm{qter}) \\
{[3] / 46, \text { idem,tas }(8 ; 12)(\mathrm{qter} ; \mathrm{qter})[2]}\end{array}$ & Exon $2-$ Exon 6 & $\begin{array}{c}\text { Present } \\
\text { case }\end{array}$ \\
\hline
\end{tabular}

a prominent thin-walled vasculature, but the tumor cells were negative. The tumor cells were additionally negative for S100, Sox10, desmin, H-caldesmon, synaptophysin, CD45, CD30, and ETSrelated gene protein (ERG).

G-banding and FISH analyses. Fresh tissue from a representative area of the tumor was short-term cultured and analyzed cytogenetically as previously described (8).

FISH was performed on metaphase spreads using the Cytocell CHOP (DDIT3 on 12q13.3) break-apart FISH Probe (Cytocell, Oxford Gene Technology, Begbroke, Oxfordshire, UK). According to the company's information, the $C H O P$ break-apart probe consists of a proximal to the centromere red $146 \mathrm{~kb}$ probe and a distal to the centromere green $165 \mathrm{~kb}$ probe, which are positioned on each side of the DDIT3 (CHOP) gene. However, the genes INHBC, INHBE, GLI1, ARHGAP9, MARS, DDIT3, and MBD6 map between the red and the green probes. Thus, the probe is not specific for the DDIT3 rearrangement but can be used to investigate possible rearrangements of any of the abovementioned genes. In the present study, we used it to look for GLI1 rearrangements. Fluorescent signals were captured and analyzed using the CytoVision system (Leica Biosystems, Newcastle, UK).

Reverse transcription (RT) PCR analysis. In order to confirm the presence of an $A C T B-G L I 1$ fusion transcript (see below), reverse transcription (RT) polymerase chain reaction (PCR) and Sanger sequencing analyses were performed as previously described (9). The primers used were the forward ACT61F (5'-CCGCCAGCTCACC
ATGGATGATG-3') and the reverse GLI720R (5'-AGGTCCTC CCGCCCATCCAGC-3') (1). The quality of the cDNA synthesis was assessed by amplification of a cDNA fragment of the $A B L$ protooncogene 1, non-receptor tyrosine kinase $(A B L 1)$ gene using the primers ABL1-91F1 (5'-CAGCGGCCAGTAGCATCTGACTTTG-3') and ABL1-404R1 (5'-CTCAGCAGATACTCAGCGGCATTGC-3'). PCR cycling was at $94^{\circ} \mathrm{C}$ for $30 \mathrm{~s}$ followed by 35 cycles of $7 \mathrm{~s}$ at $98^{\circ} \mathrm{C}$, $30 \mathrm{~s}$ at $60^{\circ} \mathrm{C}, 30 \mathrm{~s}$ at $72^{\circ} \mathrm{C}$, and a final extension for $5 \mathrm{~min}$ at $72^{\circ} \mathrm{C}$.

\section{Results}

G-banding analysis of short-term cultured cells from the tumor yielded the karyotype $46, \mathrm{XX}, \operatorname{der}(7) \mathrm{t}(7 ; 12)(\mathrm{p} 22 ; \mathrm{q} 13)$, $\operatorname{der}(12) \mathrm{t}(1 ; 12)(\mathrm{q} 12 ; \mathrm{q} 13)[11] / 46$, idem, $\operatorname{tas}(\mathrm{X} ; 8)(\mathrm{q} 28 ; \mathrm{q} 24)[3] / 46$, idem,tas(8;12)(q24;q24)[2] (Figure 2).

FISH analysis using the $C H O P$ break-apart probe (Figure $3 \mathrm{~A}$ and $\mathrm{B}$ ) showed that the distal part of the probe (green signal) hybridized to the $\operatorname{der}(7) \mathrm{t}(7 ; 12)(\mathrm{p} 22 ; \mathrm{q} 13)$, whereas the proximal part of the probe (red signal) hybridized to $\operatorname{der}(12) t(1 ; 12)(q 12 ; q 13)$ (Figure 3C).

RT-PCR amplified a 264 bp cDNA fragment. Sanger sequencing showed that it was an ACTB-GLII chimeric fragment in which exon 2 of $A C T B$ (nt 207 in the sequence with accession number NM_001101.5) fused with exon 6 of GLI1 (nt 613 in the sequence with accession number NM_005269.2) (Figure 4). 
$\mathbf{A}$

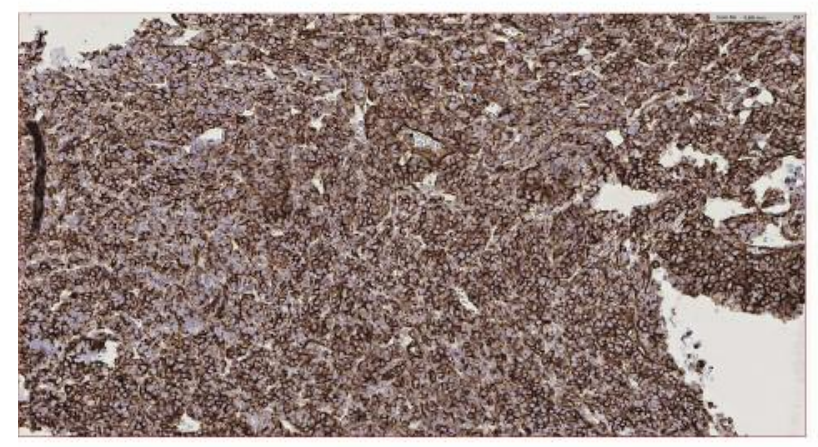

C

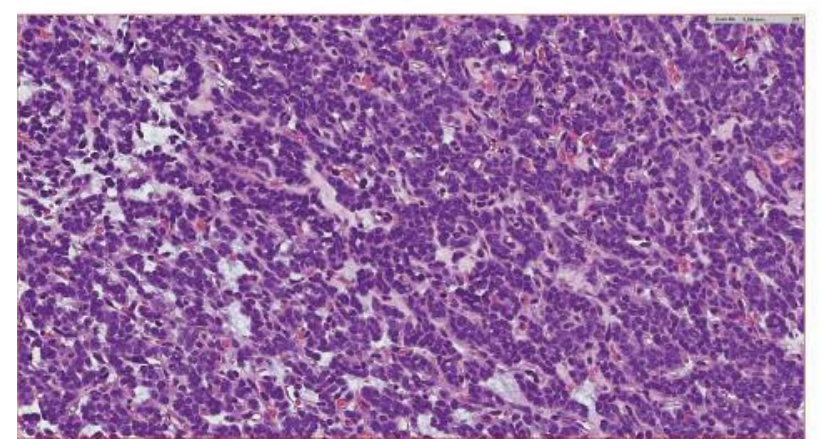

\section{B}

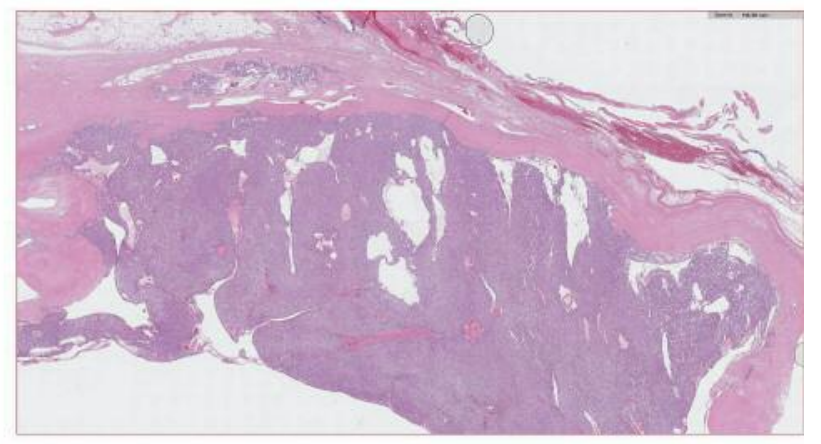

D

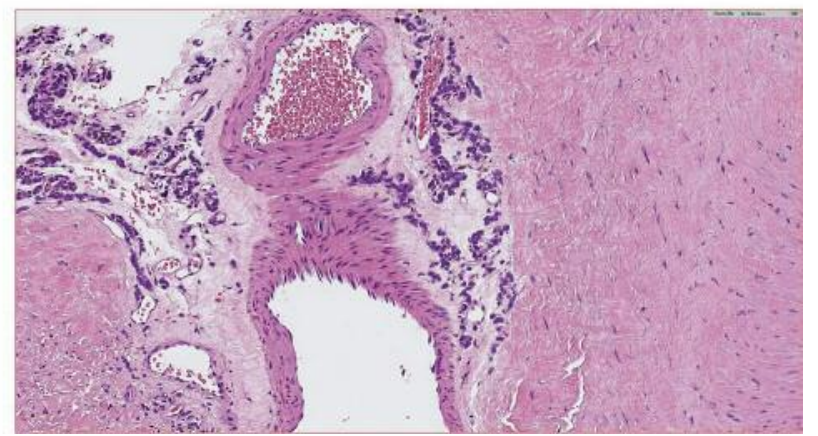

Figure 1. Microscopic examination of the pericytoma. A) Immunohistochemical examination showing expression of CD99 in the pericytoma, 40x. $B)$ Hematoxylin and eosin $(H \& E)$-stained section showing area of encapsulated tumor, $1 \times . C) H \& E$-stained section showing sheet-like growth with an intricate network of capillary-sized vessels, 40x.D) H\&E-stained section showing perivascular orientation of tumor cells, 20x.

\section{Discussion}

Since the first description in 2004 of "pericytoma with $\mathrm{t}(7 ; 12)$ " in five tumors $(1)$, only three new pericytomas were studied by both cytogenetics and molecular techniques (Table I). On the chromosome level, all eight tumors reported in literature were in diploid range (45-46 chromosomes). Half of the pericytomas had a sole $t(7 ; 12)$, two more tumors carried 1-2 additional changes, whereas the other two had complex karyotypes. All but one tumor showed visibly balanced $t(7 ; 12)$ (Table I).

The present case also had a simple diploid karyotype, accompanied by two subclones with supplementary telomeric associations. The tumor did not carry a balanced $t(7 ; 12)$ chromosome translocation, but instead a $\operatorname{der}(7) \mathrm{t}(7 ; 12)(\mathrm{p} 22 ; \mathrm{q} 13)$ and $a \operatorname{der}(12) \mathrm{t}(1 ; 12)(\mathrm{q} 12 ; \mathrm{q} 13)$. The FISH analyses not only supported the cytogenetic data but further located the pathogenetic ACTB-GLII fusion gene on the $\operatorname{der}(7)$.

The $\mathrm{t}(7 ; 12) / \operatorname{der}(7) \mathrm{t}(7 ; 12)$ places $G L I 1$ under the control of the strong $A C T B$ promoter resulting in activation of GLII and deregulation of its downstream targets $(1-7,10,11)$. According to the NCBI database, $A C T B$ is ubiquitously expressed in 27 tissue types. The highest expression was found in the appendix having 2395.4 RPKM (Reads Per Kilobase of transcript, per Million mapped reads) whereas the lowest was in the pancreas with 95.5 RPKM (12). In the same 27 tissues, GLII is weakly expressed. The highest GLII expression was found in the endometrium with 5.6 RPKM followed by expression in the testis (2.9 RPKM) and the gall bladder (2.5 RPKM) (13).

GLI1 together with GLI2 (on 2q14.2), GLI3 (on 7p14.1), and GLI4 (on 8q24.3) make up the GLI family of transcription factors (14). They bind to the DNA consensus sequence 5'-GACCACCCA-3' - in the promoters of target genes regulating their expression (15). The GLI1 protein is a transcription activator, GLI2 is both an activator and a repressor, GLI3 functions as a repressor, whereas there is no information on the function of GLI4 (16). The members of the GLI family are main mediators of the highly conserved Hedgehog signaling pathway, which plays a critical role in embryonic development (17-20). Aberrant Hedgehog signaling is associated with the development and progression of various types of cancer and is implicated in multiple aspects of tumorigenesis (21-27). 


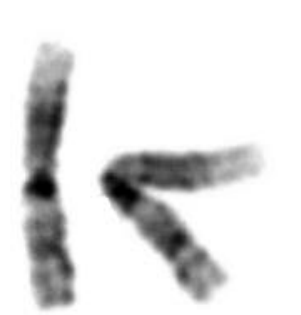

1

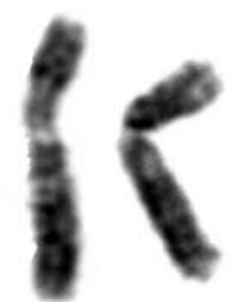

2

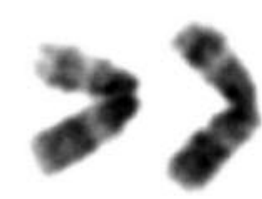

3

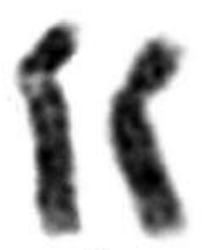

4

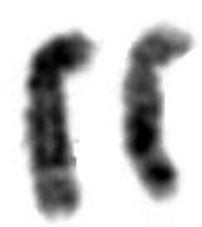

5

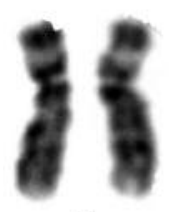

6

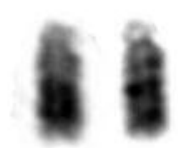

13

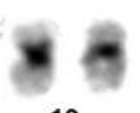

19

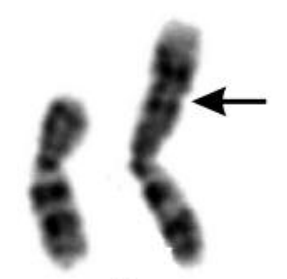

7

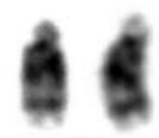

14

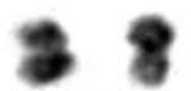

20

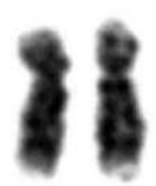

8

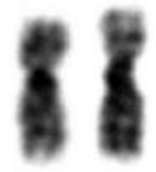

9

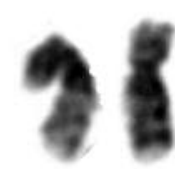

10

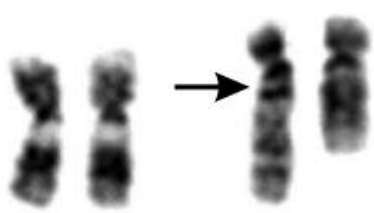

11

12

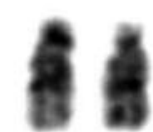

15

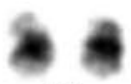

21

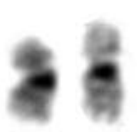

16

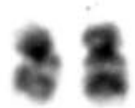

17

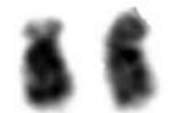

18

Figure 2. Karyogram of the pericytoma showing two abnormal chromosomes, der(7)t(7;12)(p22;q13), and der(12)t(1;12)(q12;q13). Breakpoint positions are indicated by arrows.

Three transcript variants have been reported for GLII. Transcript variant 1 (NM_005269) codes for a 1106 amino acid (aa) protein (NP_005260; isoform 1).

GLI1 isoform 1 contains (from $\mathrm{N}$ to $\mathrm{C}$ terminal) a Snail/Gfi-1(SNAG) domain, an N-terminal degradation signal, $\mathrm{D}_{\mathrm{N}}$ degron, an $\mathrm{N}$-terminal binding site for Suppressor of Fused protein (SUFU binding site), a forkhead box protein (FOXP) coiled-coil domain, 5 Cys2-His2 (C2H2) Zn-finger motifs, a nuclear localization signal, a C-terminal degradation signal, $\mathrm{D}_{\mathrm{c}}$ degron, a nuclear export signal, a $\mathrm{C}$ terminal SUFU binding site, and the transactivation domain (28-31).

Transcript variant 2 (NM_001160045) lacks the first two coding exons of transcript variant 1 , transcription initiation occurs from an internal AUG site, and codes for $\mathrm{N}$ terminally truncated protein isoform 2 (NP_001153517), also known as GLI1DeltaN (32). The GLI1 isoform 2 lacks the first 128 amino acids of GLI1 isoform 1 which contain the SNAG domain, the $\mathrm{D}_{\mathrm{N}}$ degron, and the SUFU binding site
$(29,31,32)$. Inhibition of GLI1 activity by the SUFU protein has been reported $(29,30)$.

The GLI1 transcript variant 3 (NM_001167609) has an in-frame deletion of 123 bases (41 codons) spanning the entire exon 3 and part of exon 4 of the GLII gene (33). This transcript codes for the GLI1 isoform 3 protein (NP_001161081), also known as tGLI1 (33). GLI1 transcript variant 3 was highly expressed in glioblastoma multiforme and other cancers but has not been detected in normal cells. It promotes cancer cell migration and activates a different set of genes from those activated by GLI1 isoform 1 (33).

The chimeric ACTB-GLII transcript described here is an in-frame fusion of exon 2 of $A C T B$ with exon 6 of GLII coding for a putative 969 aa protein in which the first 177 aa of GLI1 are replaced with the first 41 aa of ACTB. In fact, in all reported $A C T B-G L I 1$ chimeric transcripts, exons 1, 2, or 3 of $A C T B$ are fused to exons 5, 6 (most commonly), or 7 of $\operatorname{GLII}(1,3-5,7)$. 


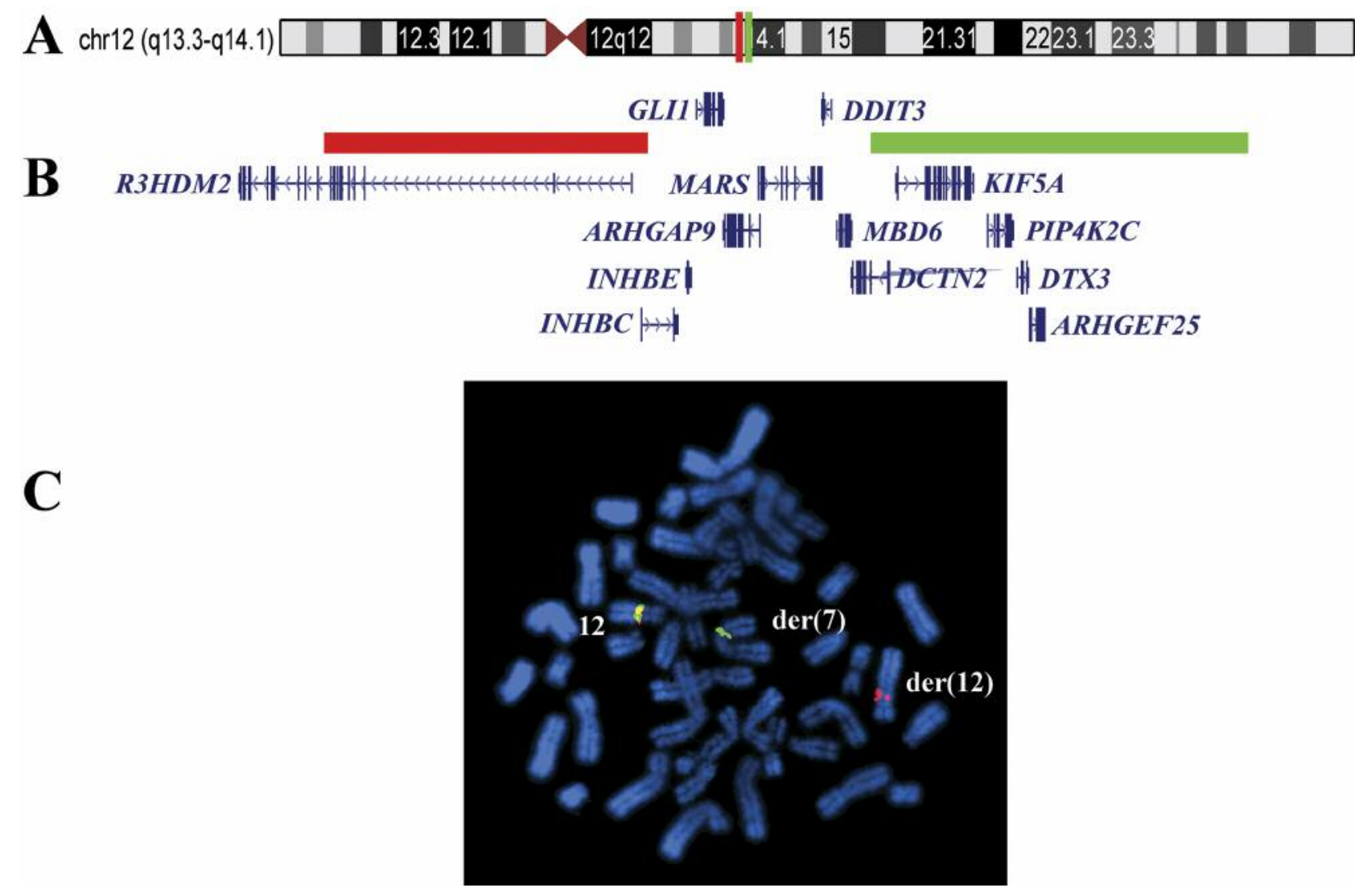

Figure 3. FISH analysis of the pericytoma with the Cytocell CHOP (DDIT3) (12q13.3) break-apart FISH Probe. A) Ideogram of chromosome 12 showing the mapping position of the FISH probe. B) Diagram showing the FISH probe and the genes covered by the probe.C) FISH on a metaphase spread showing that the distal part of the probe (green signal) hybridized to the $\operatorname{der}(7) t(7 ; 12)(p 22 ; q 13)$ whereas the proximal part of the probe (red signal) hybridized to der(12)t(1;12)(q12;q13). Both distal and proximal parts of the probe hybridized to the normal chromosome 12 .

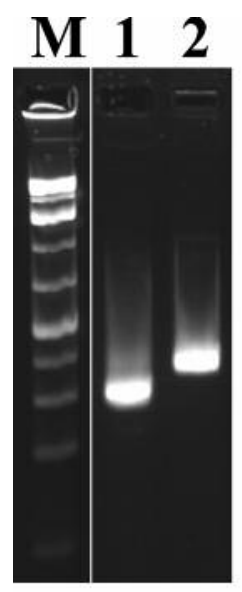

A

\section{$A C T B$ exon $2 \downarrow G L I 1$ exon 6}

G T G G G G C G C C C CA G G C C CA G C T GA A T C T GA G C T G G A A T

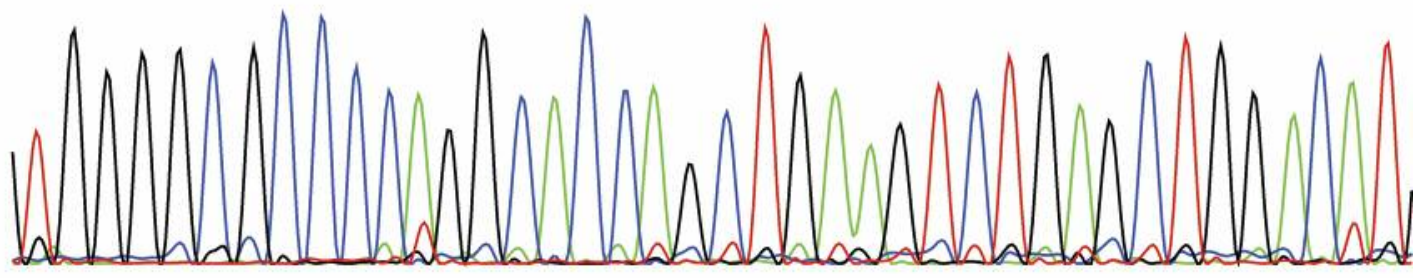

B

Figure 4. RT-PCR and Sanger sequencing. A) Gel electrophoresis showing the amplified ACTB-GLII cDNA fragment using the primer combination ACT61F/ GLI720R (lane 1) and an amplified ABL1 cDNA using the primers ABL1-91F1 and ABL1-404R1 (lane 2). M, GeneRuler 1 Kb Plus DNA ladder (ThermoFisher Scientific). B) Partial sequence chromatograms of the cDNA amplified fragment showing the junction position of exon 2 of ACTB with exon 6 of GLII. 
Recently, the MALAT1-GLII fusion gene was reported in a subset of plexiform fibromyxomas, in gastroblastomas, and in epithelioid tumors with metastatic potential $(5,34,35)$. The MALATI gene (on 11q13.1) is ubiquitously expressed and produces a long non-coding RNA $(36,37)$. Part of MALAT1 was fused to exon 6 (plexiform fibromyxomas) or to the last $19 \mathrm{nt}$ of the $145 \mathrm{bp}$ long exon 5 (gastroblastoma) of GLII $(34,35)$. Spans et al. (34) showed that the truncated GLI1 protein (lacking exons 1-5) was transcriptionally active.

A PTCH1-GLI1 fusion has also been found in an epithelioid tumor with metastatic potential (5). In that case, exon 1C of PTCHI fused to exon 7 of GLII (PTCHI transcript variant 1a, accession number NM_001083602.2) $(38,39)$. The only contribution of exon 1C PTCHI was the initiation ATG codon. Expression of exon $1 \mathrm{C}$ of $\mathrm{PTCH} 1$ was reported to be tissue specific, found in the adult brain, placenta, lung, kidney, pancreas, and in fetal kidney (38).

Taking the information reviewed above into consideration, we conclude that the ACTB-GLI1, MALATI-GLII, and PTCH1-GLII fusion genes code for proteins which are similar to the GLI1 isoform 2 protein. They contain the GLI1 FOXP coiled-coil domain, the $5 \mathrm{C} 2 \mathrm{H} 2 \mathrm{Zn}$-finger motifs, the nuclear localization signal, the $\mathrm{C}$-terminal degradation signal, $\mathrm{D}_{\mathrm{c}}$ degron, nuclear export signal, the C-terminal SUFU binding site, and the transactivation domain. They will lack the SNAG domain, the $\mathrm{N}$-terminal degradation signal, $\mathrm{D}_{\mathrm{N}}$ degron, and the N-terminal SUFU binding site. The expression of these proteins will be controlled by strong (ACTB and MALATI) or tissue specific ( $P T C H 1)$ promoters.

\section{Conflicts of Interest}

The Authors declare that no potential conflicts of interest exist.

\section{Authors' Contributions}

IP designed and supervised the research, performed molecular genetic experiments, bioinformatics analysis, and wrote the article. LG performed cytogenetic analysis and evaluated the FISH data. TVR performed the pathological examination. KA performed molecular genetic experiments, FISH analysis, and evaluated the data. FM supervised the research. SH assisted with experimental design and writing of the article. All Authors read and approved the final article.

\section{Acknowledgements}

This work was supported by grants from Radiumhospitalets Legater.

\section{References}

1 Dahlén A, Fletcher CD, Mertens F, Fletcher JA, Perez-Atayde AR, Hicks MJ, Debiec-Rychter M, Sciot R, Wejde J, Wedin R, Mandahl N and Panagopoulos I: Activation of the GLI oncogene through fusion with the beta-actin gene $(A C T B)$ in a group of distinctive pericytic neoplasms: pericytoma with $\mathrm{t}(7 ; 12)$. Am $\mathrm{J}$ Pathol 164(5): 1645-1653, 2004. PMID: 15111311. DOI: 10.1016/s0002-9440(10)63723-6

2 Dahlén A, Mertens F, Mandahl N and Panagopoulos I: Molecular genetic characterization of the genomic ACTB-GLI fusion in pericytoma with $\mathrm{t}(7 ; 12)$. Biochem Biophys Res Commun 325(4): 1318-1323, 2004. PMID: 15555571. DOI: 10.1016/j.bbrc.2004.10.172

3 Bridge JA, Sanders K, Huang D, Nelson M, Neff JR, Muirhead D, Walker C, Seemayer TA and Sumegi J: Pericytoma with $\mathrm{t}(7 ; 12)$ and ACTB-GLII fusion arising in bone. Hum Pathol 43(9): 1524-1529, 2012. PMID: 22575261. DOI: 10.1016/j.humpath.2012.01.019

4 Castro E, Cortes-Santiago N, Ferguson LM, Rao PH, Venkatramani $\mathrm{R}$ and Lopez-Terrada $\mathrm{D}$ : Translocation $\mathrm{t}(7 ; 12)$ as the sole chromosomal abnormality resulting in ACTB-GLI1 fusion in pediatric gastric pericytoma. Hum Pathol 53:137-141, 2016. PMID: 26980027. DOI: 10.1016/j.humpath.2016.02.015

5 Antonescu CR, Agaram NP, Sung YS, Zhang L, Swanson D and Dickson BC: A distinct malignant epithelioid neoplasm with GLI1 gene rearrangements, frequent $\mathrm{S} 100$ protein expression, and metastatic potential: Expanding the spectrum of pathologic entities with ACTB/MALAT1/PTCH1-GLI1 fusions. Am J Surg Pathol 42(4): 553-560, 2018. PMID: 29309307. DOI: 10.1097/PAS.0000000000001010

6 Kerr DA, Pinto A, Subhawong TK, Wilky BA, Schlumbrecht MP, Antonescu CR, Nielsen GP and Rosenberg AE: Pericytoma with $\mathrm{t}(7 ; 12)$ and $A C T B-G L I 1$ fusion: Reevaluation of an unusual entity and its relationship to the spectrum of GLI1 fusion-related neoplasms. Am J Surg Pathol 43(12): 1682-1692, 2019. PMID: 31567194. DOI: 10.1097/PAS.0000000000001360

7 Koh NWC, Seow WY, Lee YT, Lam JCM and Lian DWQ: Pericytoma with $\mathrm{t}(7 ; 12)$ : The first ovarian case reported and a review of the literature. Int J Gynecol Pathol 38(5): 479-484, 2019. PMID: 30085941. DOI: 10.1097/PGP.0000000000000542

8 Panagopoulos I, Gorunova L, Andersen HK, Pedersen TD, Lomo J, Lund-Iversen M, Micci F and Heim S: Genetic characterization of myoid hamartoma of the breast. Cancer Genomics Proteomics 16(6): 563-568, 2019. PMID: 31659109. DOI: 10.21873/cgp.20158

9 Panagopoulos I, Lobmaier I, Gorunova L and Heim S: Fusion of the genes WWTRI and FOSB in pseudomyogenic hemangioendothelioma. Cancer Genomics Proteomics 16(4): 293-298, 2019. PMID: 31243110. DOI: 10.21873/cgp.20134

10 Ng SY, Gunning P, Eddy R, Ponte P, Leavitt J, Shows T and Kedes L: Evolution of the functional human beta-actin gene and its multipseudogene family: conservation of noncoding regions and chromosomal dispersion of pseudogenes. Mol Cell Biol 5(10): 2720-2732, 1985. PMID: 3837182. DOI: 10.1128/mcb.5.10.2720

$11 \mathrm{Ng}$ SY, Gunning P, Liu SH, Leavitt J and Kedes L: Regulation of the human beta-actin promoter by upstream and intron domains. Nucleic Acids Res 17(2): 601-615, 1989. PMID: 2915924. DOI: $10.1093 / \mathrm{nar} / 17.2 .601$

12 National Center for Biotechnology Information: ACTB actin beta [Homo sapiens (human)], 2020. Available at: https://www.ncbi.nlm.nih.gov/gene/60\#gene-expression (Last accessed on 5th January 2020)

13 National Center for Biotechnology Information: GLI1 GLI family zinc finger 1 [Homo sapiens (human)], 2020 Available at: https://www.ncbi.nlm.nih.gov/gene/60\#gene-expression (Last accessed on 13th January 2020) 
14 Ruppert JM, Kinzler KW, Wong AJ, Bigner SH, Kao FT, Law ML, Seuanez HN, O'Brien SJ and Vogelstein B: The GLIKruppel family of human genes. Mol Cell Biol 8(8): 3104-3113, 1988. PMID: 2850480. DOI: $10.1128 / \mathrm{mcb} .8 .8 .3104$

15 Kinzler KW and Vogelstein B: The GLI gene encodes a nuclear protein which binds specific sequences in the human genome Mol Cell Biol 10(2): 634-642, 1990. PMID: 2105456. DOI: 10.1128/mcb.10.2.634

16 Palle K, Mani C, Tripathi K and Athar M: Aberrant GLI1 Activation in DNA damage response, carcinogenesis and chemoresistance. Cancers (Basel) 7(4): 2330-2351, 2015. PMID: 26633513. DOI: $10.3390 /$ cancers 7040894

17 Ingham PW and McMahon AP: Hedgehog signaling in animal development: paradigms and principles. Genes Dev 15(23): 3059-3087, 2001. PMID: 11731473. DOI: 10.1101/gad.938601

18 Armas-Lopez L, Zuniga J, Arrieta O and Avila-Moreno F: The Hedgehog-GLI pathway in embryonic development and cancer: implications for pulmonary oncology therapy. Oncotarget $8(36)$ : 60684-60703, 2017. PMID: 28948003. DOI: 10.18632/ oncotarget.19527

19 Carballo GB, Honorato JR, de Lopes GPF and Spohr T: A highlight on Sonic hedgehog pathway. Cell Commun Signal 16(1): 11, 2018. PMID: 29558958. DOI: 10.1186/s12964-018-0220-7

20 Sabol M, Trnski D, Musani V, Ozretic P and Levanat S: Role of GLI transcription factors in pathogenesis and their potential as new therapeutic targets. Int J Mol Sci 19(9), 2018. PMID: 30158435. DOI: $10.3390 / \mathrm{ijms} 19092562$

21 Thayer S: The emerging role of the hedgehog signaling pathway in gastrointestinal cancers. Clin Adv Hematol Oncol 2(1): 17, 20, 63, 2004. PMID: 16163153.

22 Caro I and Low JA: The role of the hedgehog signaling pathway in the development of basal cell carcinoma and opportunities for treatment. Clin Cancer Res 16(13): 3335-3339, 2010. PMID: 20439455. DOI: 10.1158/1078-0432.CCR-09-2570

23 Cochrane CR, Szczepny A, Watkins DN and Cain JE: Hedgehog signaling in the maintenance of cancer stem cells. Cancers (Basel) 7(3): 1554-1585, 2015. PMID: 26270676. DOI: $10.3390 /$ cancers 7030851

24 Fattahi S, Pilehchian Langroudi $M$ and Akhavan-Niaki H: Hedgehog signaling pathway: Epigenetic regulation and role in disease and cancer development. J Cell Physiol 233(8): 57265735, 2018. PMID: 29380372. DOI: 10.1002/jcp.26506

25 Sari IN, Phi LTH, Jun N, Wijaya YT, Lee S and Kwon HY: Hedgehog signaling in cancer: a prospective therapeutic target for eradicating cancer stem cells. Cells 7(11), 2018. PMID: 30423843. DOI: $10.3390 /$ cells 7110208

26 Skoda AM, Simovic D, Karin V, Kardum V, Vranic S and Serman L: The role of the Hedgehog signaling pathway in cancer: A comprehensive review. Bosn J Basic Med Sci 18(1): 8-20, 2018. PMID: 29274272. DOI: 10.17305/bjbms.2018.2756

27 Pietrobono S, Gagliardi S and Stecca B: Non-canonical Hedgehog signaling pathway in cancer: Activation of GLI transcription factors beyond smoothened. Front Genet 10: 556, 2019. PMID: 31244888. DOI: 10.3389/fgene.2019.00556

28 Yoon JW, Liu CZ, Yang JT, Swart R, Iannaccone P and Walterhouse D: GLI activates transcription through a herpes simplex viral protein 16-like activation domain. J Biol Chem 273(6): 3496-3501, 1998. PMID: 9452474 . DOI: $10.1074 / j b c .273 .6 .3496$
29 Dunaeva M, Michelson P, Kogerman P and Toftgard R: Characterization of the physical interaction of Gli proteins with SUFU proteins. J Biol Chem 278(7): 5116-5122, 2003. PMID: 12426310. DOI: $10.1074 /$ jbc.M209492200

30 Merchant M, Vajdos FF, Ultsch M, Maun HR, Wendt U, Cannon J, Desmarais W, Lazarus RA, de Vos AM and de Sauvage FJ: Suppressor of fused regulates Gli activity through a dual binding mechanism. Mol Cell Biol 24(19): 8627-8641, 2004. PMID: 15367681. DOI: 10.1128/MCB.24.19.8627-8641.2004

31 Huntzicker EG, Estay IS, Zhen H, Lokteva LA, Jackson PK and Oro AE: Dual degradation signals control Gli protein stability and tumor formation. Genes Dev 20(3): 276-281, 2006. PMID: 16421275. DOI: $10.1101 / \mathrm{gad} .1380906$

32 Shimokawa T, Tostar U, Lauth M, Palaniswamy R, Kasper M, Toftgard R and Zaphiropoulos PG: Novel human gliomaassociated oncogene 1 (GLI1) splice variants reveal distinct mechanisms in the terminal transduction of the hedgehog signal. J Biol Chem 283(21): 14345-14354, 2008. PMID: 18378682. DOI: $10.1074 /$ jbc.M800299200

33 Lo HW, Zhu H, Cao X, Aldrich A and Ali-Osman F: A novel splice variant of GLI1 that promotes glioblastoma cell migration and invasion. Cancer Res 69(17): 6790-6798, 2009. PMID: 19706761. DOI: 10.1158/0008-5472.CAN-09-0886

34 Spans L, Fletcher CD, Antonescu CR, Rouquette A, Coindre JM, Sciot R and Debiec-Rychter M: Recurrent MALAT1-GLI1 oncogenic fusion and GLI1 up-regulation define a subset of plexiform fibromyxoma. J Pathol 239(3): 335-343, 2016. PMID: 27101025. DOI: $10.1002 /$ path .4730

35 Graham RP, Nair AA, Davila JI, Jin L, Jen J, Sukov WR, Wu TT, Appelman HD, Torres-Mora J, Perry KD, Zhang L, KloftNelson SM, Knudson RA, Greipp PT and Folpe AL: Gastroblastoma harbors a recurrent somatic MALAT1-GLI1 fusion gene. Mod Pathol 30(10): 1443-1452, 2017. PMID: 28731043. DOI: $10.1038 /$ modpathol.2017.68

36 Zhang X, Hamblin MH and Yin KJ: The long noncoding RNA Malat1: Its physiological and pathophysiological functions. RNA Biol 14(12): 1705-1714, 2017. PMID: 28837398. DOI: $10.1080 / 15476286.2017 .1358347$

37 Zhao M, Wang S, Li Q, Ji Q, Guo P and Liu X: MALAT1: A long non-coding RNA highly associated with human cancers. Oncol Lett 16(1): 19-26, 2018. PMID: 29928382. DOI: 10.3892/ol.2018.8613

38 Shimokawa T, Rahnama F and Zaphiropoulos PG: A novel first exon of the Patched1 gene is upregulated by Hedgehog signaling resulting in a protein with pathway inhibitory functions. FEBS Lett 578(1-2): 157-162, 2004. PMID: 15581634. DOI: 10.1016/j.febslet.2004.11.006

39 Shimokawa T, Svard J, Heby-Henricson K, Teglund S, Toftgard $\mathrm{R}$ and Zaphiropoulos PG: Distinct roles of first exon variants of the tumor-suppressor Patched1 in Hedgehog signaling. Oncogene 26(34): 4889-4896, 2007. PMID: 17310997. DOI: 10.1038/sj.onc.1210301
Received January 23, 2020

Revised February 2, 2020

Accepted February 3, 2020 